University of Nebraska - Lincoln

DigitalCommons@University of Nebraska - Lincoln

USDA National Wildlife Research Center - Staff Publications
U.S. Department of Agriculture: Animal and Plant Health Inspection Service

2019

\title{
Carrion Availability in Space and Time
}

Marcos Moleón

Nuria Selva

David M. Bailey

David M. Bailey

Ainara Cortés-Avizanda

See next page for additional authors

Follow this and additional works at: https://digitalcommons.unl.edu/icwdm_usdanwrc

Part of the Natural Resources and Conservation Commons, Natural Resources Management and Policy Commons, Other Environmental Sciences Commons, Other Veterinary Medicine Commons, Population Biology Commons, Terrestrial and Aquatic Ecology Commons, Veterinary Infectious Diseases Commons, Veterinary Microbiology and Immunobiology Commons, Veterinary Preventive Medicine, Epidemiology, and Public Health Commons, and the Zoology Commons

This Article is brought to you for free and open access by the U.S. Department of Agriculture: Animal and Plant Health Inspection Service at DigitalCommons@University of Nebraska - Lincoln. It has been accepted for inclusion in USDA National Wildlife Research Center - Staff Publications by an authorized administrator of DigitalCommons@University of Nebraska - Lincoln. 
Authors

Marcos Moleón, Nuria Selva, David M. Bailey, David M. Bailey, Ainara Cortés-Avizanda, and Travis L. DeVault 


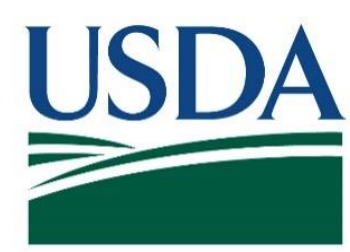

U.S. Department of Agriculture

U.S. Government Publication

Animal and Plant Health Inspection Service

Wildlife Services 


\title{
Carrion Availability in Space and Time
}

\author{
Marcos Moleón, Nuria Selva, Maria Martina Quaggiotto, David M. Bailey, \\ Ainara Cortés-Avizanda, and Travis L. DeVault
}

\section{Contents}

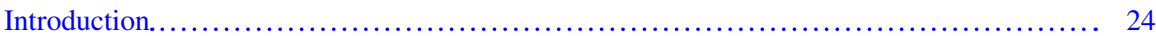

Causes of Carrion Production.................................................. 24

Estimates of Carrion Production............................................... 25

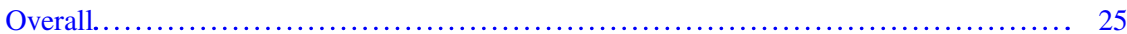

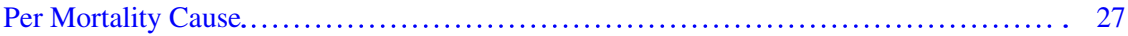

Carrion Production in Relation to Species and Individuals.......................... 28

Factors Modulating Carrion Availability and Quality ............................... 29

Spatial Variation in Carrion Availability .......................................... 31

Terrestrial Ecosystems.................................................... 32

Aquatic Ecosystems........................................................ 33

Temporal Variation in Carrion Availability .......................................... 34

Terrestrial Ecosystems................................................... 34

Aquatic Ecosystems........................................................ 35

Carrion Exchange at the Terrestrial-Aquatic Interface............................... 35

Conclusions and Future Perspectives. ........................................ 37

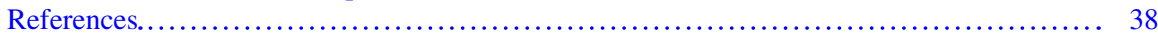

M. Moleón $(\square)$

Departamento de Biología Aplicada, Universidad Miguel Hernández, Alicante, Spain

Department of Conservation Biology, Doñana Biological Station (EBD-CSIC), Seville, Spain

Department of Zoology, University of Granada, Granada, Spain

N. Selva

Institute of Nature Conservation, Polish Academy of Sciences, Kraków, Poland

M. M. Quaggiotto · D. M. Bailey

Institute of Biodiversity, Animal Health and Comparative Medicine, College of Medical,

Veterinary and Life Sciences, University of Glasgow, Glasgow, UK

e-mail: david.bailey@glasgow.ac.uk

A. Cortés-Avizanda
Department of Conservation Biology, Doñana Biological Station (EBD-CSIC), Seville, Spain

Animal Ecology and Demography Group, IMEDEA (CSIC-UIB), Palma de Mallorca, Spain

T. L. DeVault

US Department of Agriculture, Animal and Plant Health Inspection Service, Wildlife

Services, National Wildlife Research Center, Sandusky, OH, USA

e-mail: travis.1.devault@aphis.usda.gov

(C) Springer Nature Switzerland AG 2019

P. P. Olea et al. (eds.), Carrion Ecology and Management, Wildlife Research

Monographs 2, https://doi.org/10.1007/978-3-030-16501-7_2 


\section{Introduction}

Availability of carrion to scavengers is a central issue in carrion ecology and management, and is crucial for understanding the evolution of scavenging behaviour. Compared to live animals, their carcasses are relatively unpredictable in space and time in natural conditions, with a few exceptions (see below, especially Sect. "Carrion Exchange at the Terrestrial-Aquatic Interface"). Carrion is also an ephemeral food resource due to the action of a plethora of consumers, from microorganisms to large vertebrates, as well as to desiccation (i.e., loss of water content; DeVault et al. 2003; Beasley et al. 2012; Barton et al. 2013; Moleón et al. 2014). With a focus on vertebrate carcasses, here we give an overview of (a) the causes that produce carrion, (b) the rate of carrion production, (c) the factors affecting carrion quality, and (d) the distribution of carrion in space and time, both in terrestrial and aquatic environments (including their interface). In this chapter, we will focus on naturally produced carrion, whereas non-natural causes of animal mortality are described in chapter "Human-Mediated Carrion: Effects on Ecological Processes". However, throughout this chapter we also refer to extensive livestock carrion, because in the absence of strong restrictions such as those imposed in the European Community after the bovine spongiform encephalopathy crisis (Donázar et al. 2009; Margalida et al. 2010), the spatiotemporal availability of carrion of extensive livestock and wild ungulates is similar.

\section{Causes of Carrion Production}

Animals commonly die from natural causes such as predation, starvation, parasites, disease, adverse climatic conditions and accidents. Many animals die naturally during the most susceptible stages of life: early when vulnerability reduces their survival, late because of senescence. Also, animals may die from casualties related to humans (see chapter "Human-Mediated Carrion: Effects on Ecological Processes"), which include intentional mortality sources such as game hunting, fisheries, deliberate poisoning and poaching, as well as unintentional mortality causes such as collisions with infrastructures, road kills, ship strikes, emerging infectious diseases and environmental toxins (Burkholder et al. 1992; Harvell et al. 1999; Laist et al. 2001; Fisher et al. 2006; Lambertucci et al. 2010; Collins and Kays 2011; Koch et al. 2013; Jepson et al. 2013; Wright et al. 2013; Kühn et al. 2015; Benbow et al. 2016). Further, these causes of death often work in concert (Newton 1998). For instance, cold weather conditions may increase the requirement of energy intake and thus increase the risk of starvation (Begon et al. 2006; Conover et al. 2013). Moreover, animals weakened by disease are more prone to predation (Schaller 1972) and, in some cases, collisions with automobiles (Møller et al. 2011).

In terrestrial biomes, most vertebrates usually die due to predation and diseases. Food and water shortage are major drivers of herbivore mortality, either directly 
indirectly via enhancing vulnerability to predation, pathogens and others (Pereira et al. 2014). Moreover, exhaustion suffered during long-distance migrations may increase ungulate, bat, and bird mortality rates through different mechanisms (e.g., Geluso et al. 1976; Mduma et al. 1999). Apex carnivores, in contrast, mostly die as a consequence of competition (including intraguild - both inter- and intraspecifickilling; Palomares and Caro 1999; Thompson et al. 2015), parasites, and senescence.

In aquatic ecosystems, for some anadromous fish species (e.g. Pacific salmonids Onchorhynchus spp.), reproduction coincides with death. Necropsies of stranded marine mammals and turtles revealed these animals are susceptible to a wide range of parasites and viruses (Harvell et al. 1999; Arbelo et al. 2013; Work et al. 2015). Toxic diatom blooms can produce massive mortalities among sea lions (Scholin et al. 2000). Furthermore, mortality events can be also associated with large-scale climatic perturbations (Evans et al. 2005). In the South Pacific, for instance, mass mortality of Pygmy killer whales (Feresa attenuata) was linked with extreme meteorological conditions, such as the hurricanes Marylyn and Jim (Clua et al. 2014). Furthermore, fish kills can be attributed to natural conditions of oxygen deficiency (Stachowitsch 1984), extreme cold waters (Marsh et al. 1999; Hoag 2003) or river water acidification (Fjellheim and Raddum 1990). Similar to large animals in terrestrial ecosystems, whales and large sharks are probably subject to reduced predation risk and thus senescence and disease must be the most important natural causes of mortality, at least for adults.

\section{Estimates of Carrion Production}

Quantifying how much carrion is produced in ecosystems is one of the most important, although probably the most overlooked, aspect of carrion ecology (Oro et al. 2013). This is mostly due to methodological difficulties in obtaining empirical data in both terrestrial and aquatic systems. Estimating how much carrion is produced temporally and spatially is a complex issue that requires intensive fieldwork (e.g., Selva 2004), sometimes in combination with sophisticated modelling approaches (e.g., Wilmers and Getz 2004, 2005; Margalida et al. 2011).

\section{Overall}

In terrestrial ecosystems, as we show in Table 1, only a few studies have provided estimates of carrion biomass production per units of time and space in natural conditions (provision to dumps and vulture feeding stations, intensive livestock debris and game hunting remains are considered in chapter "Human-Mediated Carrion: Effects on Ecological Processes" because of their human origin). All these studies have focused on ungulates (wild, domestic or both). When all mortality causes are 
considered together, carrion is produced at an annual rate of up to ca. $700 \mathrm{~kg} / \mathrm{km}^{2}$. In all cases, carrion supply ranged between tens to hundreds of $\mathrm{kg} / \mathrm{km}^{2}$, although estimation methodologies, as well as the species evaluated, were highly heterogeneous among the reviewed studies (Table 1).

In well-preserved coastal systems, carcass supply can be substantially higher than inland. On the Isle of May (Scotland), an average of ca. $7000 \mathrm{~kg}$ of grey seal (Halichoerus grypus) placenta and dead pups and adults are produced annually, which means localised concentrations of as much as ca. $15,000 \mathrm{~kg} / \mathrm{km}^{2}$ (Quaggiotto et al. 2018). Up to $530 \mathrm{~kg} / \mathrm{km}$ of stranded carrion accumulates annually along the shoreline of the Gulf of California (Polis and Hurd 1996b), whereas seabird colonies within the same gulf provided carrion with densities ranging between 5 and $100 \mathrm{~kg} / \mathrm{km}^{2}$, depending on the nesting island (Sánchez-Piñero and Polis 2000).

Table 1 Carrion biomass $\left(\mathrm{kg} / \mathrm{km}^{2}\right)$ produced in different terrestrial systems by natural causes such as predation or disease

\begin{tabular}{|c|c|c|c|c|c|c|}
\hline Continent & Country & Location & $\begin{array}{l}\text { Carrion } \\
\text { biomass }\end{array}$ & Species & Period & Reference \\
\hline Africa & Zimbabwe & $\begin{array}{l}\text { Rural } \\
\text { Zimbabwe }\end{array}$ & 696 & $\begin{array}{l}\text { Domestic and } \\
\text { wild ungulates }\end{array}$ & Annual & $\begin{array}{l}\text { Butler and Du Toit } \\
(2002)\end{array}$ \\
\hline \multirow[t]{7}{*}{ Europe } & Poland & $\begin{array}{l}\text { Białowieża } \\
\text { Primeval } \\
\text { Forest }\end{array}$ & 89 & $\begin{array}{l}\text { All wild } \\
\text { ungulates }\end{array}$ & Annual & Selva (2004) \\
\hline & Spain & $\begin{array}{l}\text { Continental } \\
\text { Spain }\end{array}$ & 195 & $\begin{array}{l}\text { Extensive } \\
\text { livestock }\end{array}$ & Annual & $\begin{array}{l}\text { Morales-Reyes } \\
\text { et al. (2017a) }\end{array}$ \\
\hline & & $\begin{array}{l}\text { Cantabrian } \\
\text { Mountains }\end{array}$ & $2.1-40.3$ & $\begin{array}{l}\text { Extensive } \\
\text { livestock } \\
\text { (transhumant) }\end{array}$ & Annual & $\begin{array}{l}\text { Olea and } \\
\text { Mateo-Tomás } \\
\text { (2009) }\end{array}$ \\
\hline & & & $1.5-8.7$ & $\begin{array}{l}\text { Extensive } \\
\text { livestock } \\
\text { (resident) }\end{array}$ & Annual & $\begin{array}{l}\text { Olea and } \\
\text { Mateo-Tomás } \\
(2009)\end{array}$ \\
\hline & Sweden & $\begin{array}{l}\text { Sarek } \\
\text { National } \\
\text { Park }\end{array}$ & $0.6-9.6$ & $\begin{array}{l}\text { Reindeer } \\
\text { (wolverine and } \\
\text { Eurasian lynx } \\
\text { kills) }\end{array}$ & Annual & $\begin{array}{l}\text { Mattisson et al. } \\
\text { (2011) }\end{array}$ \\
\hline & UK & $\begin{array}{l}\text { Scottish } \\
\text { Highlands }\end{array}$ & 264 & $\begin{array}{l}\text { Sheep and red } \\
\text { deer }\end{array}$ & Annual & $\begin{array}{l}\text { Brown and Watson } \\
\text { (1964) }\end{array}$ \\
\hline & & $\begin{array}{l}\text { Pastoral } \\
\text { land (Wales) }\end{array}$ & 190 & Sheep & Annual & $\begin{array}{l}\text { Newton et al. } \\
(1982)\end{array}$ \\
\hline \multirow[t]{3}{*}{$\begin{array}{l}\text { North } \\
\text { America }\end{array}$} & USA & Yellowstone & 69-104 & Red deer & $\begin{array}{l}\text { Cold } \\
\text { season }\end{array}$ & Houston (1979) \\
\hline & & & $13-63$ & All ungulates & $\begin{array}{l}\text { Cold } \\
\text { season }\end{array}$ & Gese et al. (1996) \\
\hline & & & 9 & $\begin{array}{l}\text { Red deer (wolf } \\
\text { kills) }\end{array}$ & $\begin{array}{l}\text { Cold } \\
\text { season }\end{array}$ & $\begin{array}{l}\text { Wilmers et al. } \\
(2003 a, b)\end{array}$ \\
\hline $\begin{array}{l}\text { South } \\
\text { America }\end{array}$ & Chile & $\begin{array}{l}\text { Central } \\
\text { Patagonia }\end{array}$ & 0.2 & $\begin{array}{l}\text { All ungulates } \\
\text { (puma kills) }\end{array}$ & Annual & $\begin{array}{l}\text { Elbroch and } \\
\text { Wittmer (2012) }\end{array}$ \\
\hline
\end{tabular}

Studies evaluating human-mediated carrion (e.g. dumps, vulture feeding stations, intensive livestock debris or game hunting) are considered separately in Chap. 8 
Covering over $70 \%$ of the planet's surface with a volume of 1332 billion $\mathrm{km}^{3}$, the marine system is both the largest environment on earth and also one of the least accessible and least understood (Glover et al. 2010; Ramirez-Llodra et al. 2010). Natural food falls and fish carcasses are, in fact, relatively unusual observations (Soltwedel et al. 2003). This is probably because most of the seafloor is d eep (>200 m); an environment which is hard to observe and where carrion is rapidly consumed (Isaacs and Schwartzlose 1975; Bailey and Priede 2002). Considering the nine largest whale species, it has been calculated that at any given time there is a fresh (i.e., with soft tissue) whale carcass on the sea floor every $16-36 \mathrm{~km}$ (Smith and Baco 2003).

In some rivers of the North Atlantic and North Pacific regions, salmon runs may signify a massive input of nutrients. For example, rivers of the Bristol Bay in Alaska (400 km long and $290 \mathrm{~km}$ wide) receive annually around $5.4 \times 10^{7} \mathrm{~kg}$ of adult salmon from the ocean. These salmon, whose biomass was gained mostly in the sea, will die shortly after spawning, thus subsidizing a complex array of both terrestrial and fresh water scavengers and decomposers (Gende et al. 2002). Terrestrial animals can also subsidized aquatic ecosystems through the provision of carrion (Pringle 2017). For instance, the mass drowning of wildebeests (Connochaetes taurinus) crossing the Mara River in the Serengeti (Africa) during the annual migration provides an annual input of 1,100 tonnes of biomass entering the river system (Subalusky et al. 2017).

\section{Per Mortality Cause}

Both in terrestrial and aquatic systems, carrion biomass provision depends chiefly on the mortality cause. Among natural sources of mortality, the main distinction is made between carrion supplied in the form of predator kills and other sources of carrion (see Sect. "Causes of Carrion Production"). While the latter result in complete carcasses being available to scavengers, only a portion of predator kills (i.e., the part not consumed by the predator) can be accessed by scavengers. In Białowieża Forest (Poland), Selva (2004) found that 35\% of ungulate carrion was provided by disease and/or starvation, whereas predation by wolves (Canis lupus) and Eurasian lynxes (Lynx lynx) was responsible of $30 \%$ and $1 \%$ of carrion supply respectively (the remaining $34 \%$ of total ungulate carrion biomass was carrion of harvested animals left in the forest). In the Serengeti (Tanzania), 55-92\% (depending on the month) of ungulate carcass supply to vultures comes from causes other than predation (Houston 1974). The abundance and nature of the predator is also important in determining how much of the predator kill is available to scavengers (Moleón et al. 2014; Table 1). For instance, solitary carnivores and those that do not return to their kills once satiated (e.g., cheetah Acinonyx jubatus) may leave more carrion per individual carcass in general than social ones (e.g., lions Panthera leo; Hunter et al. 2006; Elbroch and Wittmer 2012) and those that guard their kills for future consumption (e.g., leopards P. pardus; Kruuk 1967; Hunter et al. 2006). 


\section{Carrion Production in Relation to Species and Individuals}

Carrion supply can also be strongly influenced by species identity, as it will determine carcass size and the rate at which carcasses are produced. Thus, large species would provide more carrion than smaller ones, and highly productive species would produce more carcasses than less productive ones (Fig. 1). Houston (1985) showed that Neotropical forests provide a greater food supply to vertebrate scavengers than Afrotropical forests due to the higher biomass and smaller average size (and thus higher average turnover) of herbivorous mammals in the former. In addition, obviously, population abundance must be considered when determining how much carrion biomass can be produced by a given species. In Białowieża Forest, red deer (Cervus elaphus) and wild boar (Sus scrofa) supply more carrion per year (3522 and $2417 \mathrm{~kg}$, respectively) than larger (moose Alces alces, $404 \mathrm{~kg}$; European bison Bison bonasus, $1600 \mathrm{~kg}$ ) and smaller ungulates (roe deer Capreolus capreolus, $100 \mathrm{~kg}$; Selva 2004).

Megaherbivores, i.e., herbivores weighing above $1000 \mathrm{~kg}$ (Owen-Smith 1988), are normally free from predation, especially as adults. Thus, megaherbivore carrion supply, mostly in the form of whole carcasses from sick, malnourished and senescent individuals, is an important contribution to the total carrion biomass in some African ecosystems, especially once depression of populations of elephants (Loxodonta africana) and other large herbivores by humans ceases and a stationary age distribution is reached (Pereira et al. 2014). The same basic pattern is expected to occur in the oceans, where whales, large sharks, marine mammals and large turtles are scarcely subject to predation (e.g., Heithaus et al. 2008).

Fig. 1 Carrion supply magnitude (high $v s$. low) in relation to the size and productivity of animals under natural conditions. Note that there are no very large and very productive animals. Credits: the chapter authors

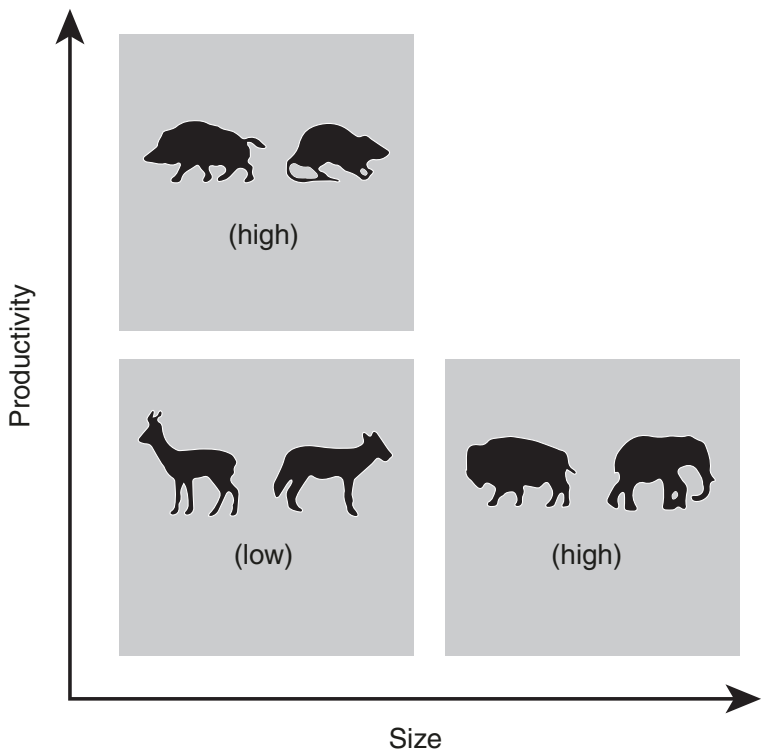


Another major factor influencing how much carrion is produced is individual identity. Sex, age and body condition strongly determines individuals' vulnerability to mortality (Pereira et al. 2014). For instance, newborns, calves and old animals (Husseman et al. 2003; Barber-Meyer et al. 2008), as well as pregnant females (Molinari-Jobin et al. 2004) and male ungulates competing for mating rights (FitzGibbon 1990), are especially vulnerable to predation.

Because of their high biomass, marine mammals are almost certainly one of the main contributors of vertebrate carrion to the marine system. However, the evidence of carcasses is rare. Marine mammal mortality is in fact estimated by monitoring their population through regular censuses, and losses from the population can be identified by simultaneous analysis of live resighting and dead recovery mark-recapture data. This method has been used to estimate an average first year survival in grey seals in Britain of ca. $20 \%$ for males and ca. $60 \%$ for females (Hall et al. 2001).

\section{Factors Modulating Carrion Availability and Quality}

The number of animals dying within and across ecosystems, the cause of death and the species and individual identity of carcasses are not the only factors influencing the amount of carrion biomass available to vertebrate scavengers. Carcass location, weather conditions and biotic interactions can greatly modulate carrion accessibility to scavengers in space and time. For scavengers that rely mainly on visual cues to detect food, vegetation cover and structure may crucially influence the rate and speed at which carrion is encountered (Ogada et al. 2012; Fig. 2). Some debilitated

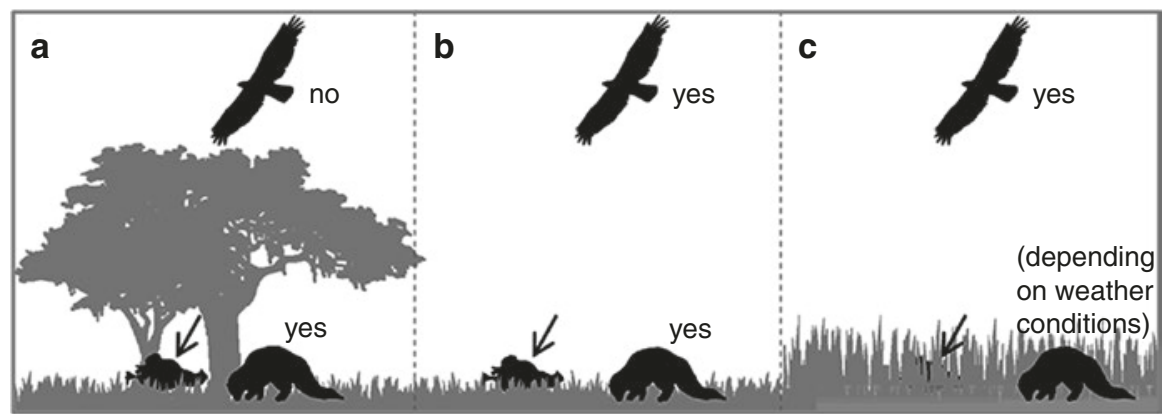

Fig. 2 Vegetation cover and structure may influence the ability of scavengers to locate carcasses (indicated by arrows). Soaring scavengers will rarely see a carcass located below dense tree canopy (a), whereas carcasses located in open habitat $(\mathbf{b}, \mathbf{c})$ may be easily found. Non-flying scavengers may readily see a carcass located within short grass, irrespective of the presence (a) or absence (b) of trees; however, they will find more difficulties in seeing a carcass located within tall grass (c). Difficulties in locating carcasses by sight can be overcome by acute sense of smell, provided that weather conditions do not dissipate odorants produced by carrion. Similar scenarios can be expected in aquatic environments. Credits: the chapter authors 
animals such as malnourished megaherbivores often die near surface water (Conybeare and Haynes 1984). Due to vegetation encroachment along river and lake margins, such carcasses may be hardly accessible to certain scavengers such as large birds. Windy and rainy conditions will limit the capacity of soaring birds such as vultures and other large raptors to forage (Houston 1979; Selva et al. 2005). Rainfall can also reduce the olfactory capacity of mammalian carnivores (Savage 1977; Ruzicka and Conover 2012). In addition, carcass location by olfactory scavengers may be constrained by high temperatures and low humidity (Ruzicka and Conover 2012). In general, large carcasses are more accessible compared to carcasses of small animals that may appear in hollows inaccessible to most scavengers (Cox and Smith 1992, but see DeVault and Krochmal 2002).

Both inter- and intra-specific interactions, mediated by differences in behavioural, ecological, morphological and physiological traits among vertebrate obligate and facultative scavengers may influence the ability to find and consume carrion (Kendall 2013; Moleón et al. 2014; Sebastián-González et al. 2016; Moreno-Opo et al. 2016. First, mentioned above, predator kills may provide important quantities of food to scavengers (e.g., Kruuk 1967). Indeed, carrion provided by predators such as wolves is increasingly important in northern areas where milder winter weather conditions are reducing the number of carcasses produced by other causes during this critical period (Wilmers et al. 2003a, b; Selva et al. 2005; Wilmers and Getz 2005; Wilmers and Post 2006; Wikenros et al. 2013). Second, predators themselves and scavengers that rapidly arrive to the carcass may signal carcass location to other scavenger species and individuals (Attwell 1963; Kruuk 1967, 1972; Prior and Weatherhead 1991; Cortés-Avizanda et al. 2012; Kendall 2013; Cortés-Avizanda et al. 2014; Kane et al. 2014). Third, large mammalian carnivores and certain vultures may facilitate access to the interior of thick-skinned carcasses to less powerful scavengers by tearing open the tough hide (Attwell 1963; Stahler et al. 2002; Selva et al. 2003). Fourth, competition, both exploitative and interference (Birch 1957; Begon et al. 2006), may limit access to carrion by competitively inferior scavengers such as small mammalian carnivores (Kruuk 1967, 1972; Schaller 1972; Houston 1974, 1979; Kendall et al. 2012; Kendall 2013; Moleón et al. 2015). In this sense, the lack of specialist carrion consumers - such as Gyps vultures that quickly locate and deplete carrion resources (Houston 1979; Sebastián-González et al. 2013; Cortés-Avizanda et al. 2014; Sebastián-González et al. 2016; Morales-Reyes et al. 2017b)—in cold environments increases the duration of carcasses and thus could favour other carrion consumers. In British Columbia (Canada), in absence of obligate scavengers, biomass of salmon carrion - which is highly predictable and easy to handle - in estuarine environment was positively related not only with the abundance of scavengers but also with the diversity of the scavenging community (Field and Reynolds 2013).

The composition of invertebrate communities also can affect the temporal availability of carcass resources and, by extension, the composition of vertebrate scavenger communities. Houston (1985) showed how fly 1 arvae c ompletely c onsume carcasses of 2-10 kg within 3 days in Afrotropical forests, whereas in Neotropical forests a complex community of ants suppresses maggot infestations on carcasses, thereby extending the availability of carcasses to vertebrates to over 10 days 
(Houston 1985, 1988). Houston (1985) speculated that this temporal regulation of the food supply by invertebrates contributed to the presence of vultures in forested regions in South America, as opposed to Africa, where vultures are confined to open savannahs and grasslands.

Microbial decomposers can quickly render carcasses inedible to most would-be scavengers by producing toxic compounds on carcasses (Janzen 1977; Burkepile et al. 2006; Shivik 2006). Microbes are more active as temperatures increase (Putman 1983; Carter et al. 2007), and several studies have demonstrated that vertebrates consume fewer available carcasses in warm weather compared to cold weather (DeVault et al. 2004; Selva et al. 2005; Parmenter and MacMahon 2009), likely due to increased activity of decomposers at higher temperatures. A factor closely related to microbial activity is carcass size: the larger the carcass, the longer the time needed to be consumed and, consequently, the greater the putrefaction (Pereira et al. 2014; Moleón et al. 2015). However, competition for food among vertebrate scavengers is reduced at very large carcasses (Moleón et al. 2015).

Similar to the terrestrial environment, the temporal availability of carrion to marine scavengers may be influenced by bacteria which affect carrion consumption. Unlike in terrestrial systems, internal decomposition may make the carcass buoyant so that it leaves the seafloor, removing carrion from the reach of some scavengers and giving access to others. Another difference in marine systems is that in large carrion items such as whale falls in deep water, the actions of bacteria result in overlapping stages of ecological succession (Bennett et al. 1994; Smith et al. 1998; Beasley et al. 2012). In these circumstances anaerobic bacterial decomposition of bone lipids (sulphophilic stage) occur after the removal of the soft tissue by necrophages (mobile-scavenger stage) and the colonisation of the bones and the nutrients-enriched sediments by assemblages of macro-benthic organisms (enrichment-opportunist stage). During decomposition, a chemosynthetic assemblage may develop where carbon is fixed from the water column using the energy released by the oxidation of sulphides in whale bones. In shallow waters, microbes were found to cover the skin of marine mammal carrion creating a bacterial mat that possibly prevents consumption by larger carrion consumers (Glover et al. 2010; Quaggiotto et al. 2016). Microbe-laden fish carrion, in fact, was colonised at lower extent than fresh carrion by scavengers such as crabs, demonstrating that bacteria can act as deterrent to scavenging activity (Burkepile et al. 2006).

\section{Spatial Variation in Carrion Availability}

The most likely place to find carrion is, of course, where live animals can be found, and more specifically, where they die (Olea and Mateo-Tomás 2009; Mateo-Tomás and Olea 2010). Thus, to determine spatial variation in carrion availability, one must consider where animals spend time during various activities. Also, because some individuals are consumed completely by predators immediately after their death and thus do not contribute to the pool of carrion available to scavengers (Houston 1974 , 
1979), spatial variation in carrion availability is also influenced by differences in cause-specific mortality across species and locations (see above). In this section, we briefly consider factors that affect carrion availability across space by examining where animals tend to die, and how the cause of death influences carrion availability across locations. First, we focus on terrestrial ecosystems, which differ from aquatic ecosystems in that animals that die on land typically do not move after death before consumption, whereas animal carcasses in water often sink, float or are moved by currents (Beasley et al. 2012; see Sect. "Aquatic Ecosystems").

\section{Terrestrial Ecosystems}

Some areas of the home range are more dangerous than others, and thus certain causes of death are associated with predictable locations. In an example highlighting particularly risky locations, male birds reduced nest visits to feed incubating females when perceived predation risk increased, suggesting that mortality is higher at the nest than elsewhere in the home range (Ghalambor and Martin 2002). Carrion also can be found predictably along migration routes and at grazing areas for wild and domestic ungulates (Houston 1974; Olea and Mateo-Tomás 2009; Kendall et al. 2014). Scavengers are known to take advantage of predictable carcass locations; for example, some scavenging birds preferentially forage for carrion along roads (Lambertucci et al. 2009).

Unfortunately, few data are available on locations of animal carcasses that die from exposure to toxins, parasites, disease, extreme elements, or starvation, as studies of cause-specific mortality rarely report this information (see Collins and Kays 2011). Even so, it seems likely that individuals dying from these causes might come to rest in less predictable locations than those that are killed by predators or human-related causes (e.g., collisions with vehicles and structures). For example, rodents exposed to anticoagulant poisons were found dead both in the open and in underground burrows (Cox and Smith 1992; Howald et al. 1999; Tuyttens and Stuyck 2002). We note that although underground carcasses might be unavailable to many scavengers, some species such as snakes could be well suited to detect, find, and consume such carcasses (Cowles and Phelan 1958; DeVault and Krochmal 2002). Sometimes, places of death are predictable at the microhabitat scale. For instance, weakened African elephants tend to die near water holes (Conybeare and Haynes 1984).

At a biogeographical scale, some patterns in carrion availability can be identified. Neotropical forests seem to provide a greater food supply to vertebrate scavengers than Afrotropical forests due to the higher biomass and average turnover of herbivorous mammals in the former (Houston 1985). In addition, as mentioned in Sect. "Factors Modulating Carrion Availability and Quality", carcasses remain available to vertebrates in Neotropical forests for longer periods than in Afrotropical forests likely due to interactions among the invertebrate community. 


\section{Aquatic Ecosystems}

Fresh marine mammal carrion may not often be detectable because it is rapidly scavenged or decomposed at sea (Gulland 2006), making it challenging to determine its distribution in space. The fact that their skeleton or bones last longer could reveal some spatial patterns. However, the discrepancy occurring between where a marine mammal dies and where its body is transported, regardless it ends up with either a fall onto the seabed or a stranding on the shore, suggests that movements of carrion in the aquatic ecosystem involve a larger spatial and three-dimensional scale than carrion originated on land (Beasley et al. 2012). In water, mobility of carrion can be facilitated not only by currents and waves, but also by body density of the carcass and decomposition processes undergoing inside it. Body composition (blubber and lean) of the carcass determines its buoyancy (Peltier et al. 2012); putrefaction gases can cause its flotation (Reisdorf et al. 2012). Pressure and temperature also concur in facilitating movements of carrion: in particular, conditions of 15 atmosphere (atm) of hydrostatic pressure prevent the re-floating of large whales (>40 tons) in cold water (Smith and Baco 2003); whereas a carcass of a harbour porpoise (Phoceona phocoena, ca. $60-70 \mathrm{~kg}$ ) at temperature above $4{ }^{\circ} \mathrm{C}$ is likely to surface in shallow waters (Moreno et al. 1992). Over the process of decomposition and consumption individual carrion items may be available to more than one type of scavenging assemblage depending on where the carcass is transported, with different consequences for the eventual fate of the energy and nutrients within it. Floating bodies may be exposed to scavenging birds when floating at the water surface or when stranded on the shore (Hewson 1995). Damage by scavenging birds may compromise the integrity of floating carcasses (Hewson 1995) and cause its sinking back to the seabed making it available again to the marine community. Overall, whale carcasses are expected to be most frequently found along migration routes and around feeding grounds, which use to be located near ocean margins (Smith and Baco 2003).

An environment where carrion is naturally available in high abundance is iceberg-scoured shallow coastal waters. Here benthic communities are periodically crushed and scraped from rocks, or ploughed into/from the sediment by the action of moving ice. Scavenger assemblages and activity are highly spatially variable. This variation can be between areas of different aspect (Smale et al. 2007) and depth (Dunlop et al. 2014). These differences presumably reflect the supply of carrion and the risk of death to the scavengers themselves. There is presumably an intermediate level of carrion impact, which is optimal for scavenging. At extremely high level of scouring there will never be much biomass to turn into carrion, with only biofilms having time to g row between impacts a nd the scavengers themselves could not survive. At very low levels of impact there will be little mortality to provide the carrion and so an intermediate level of iceberg impact is necessary (Dunlop et al. 2014).

In North Atlantic and North Pacific rivers, salmon carrion is expected to concentrate around spawning sites, where most adult mortality occurs (Gende et al. 
2002). Naturally, currents, physical barriers and consumption rates by scavengers will largely determine to which extent this pulse of salmon carrion is expanded down the river.

\section{Temporal Variation in Carrion Availability}

Much like spatial variation in carrion availability, temporal variation in carrion availability is dependent on the cause of death. Starvation, predation, disease, exposure to extreme elements, and several human-related causes of death can fluctuate substantially in magnitude and thus provide carcasses to scavengers at differing rates across the year and between years (DeVault et al. 2003; Wilson and Wolkovich 2011; Pereira et al. 2014).

\section{Terrestrial Ecosystems}

Seasonality in carrion supply is a common feature of seasonal ecosystems, where ungulate mortality resulting from causes other than predation is related to the period of the year when food availability is limited and thermal stress is maximum. In northern latitudes, this takes place during the winter, while in African savannahs, it occurs toward the end of the dry season (see Pereira et al. 2014 and references therein). These limiting conditions can be especially harsh in some years, thus producing inter-annual oscillations in carcass production. For example, herbivore carcasses in Kruger National Park are very abundant during disease outbreaks and severe droughts, to the point that a number of them may remain uneaten (Owen-Smith and Mills 2008).

Although carrion resources are often produced in pulses, in some areas carrion is present consistently across the year and between years at the landscape scale. This consistency in available carrion is evident by the occurrence of resident vulture communities (e.g., across much of the Americas and parts of Africa, Asia and Europe), which subsist almost exclusively on carrion (Houston 1979; DeVault et al. 2003; Moleón et al. 2014).

Carrion availability through time can be strongly influenced by vertebrate predators. In one well documented example, Wilmers and colleagues (Wilmers et al. 2003a; Wilmers and Getz 2004, 2005; Wilmers and Post 2006) studied how carrion resources in Yellowstone National Park, USA, changed after the reintroduction of wolves. They found that predation on elk by wolves changed the nature of carrion available to scavengers from a predominantly pulsed resource resulting from a latewinter influx of whole carcasses (caused by starvation of elk and other herbivores in harsh environmental conditions) to a more temporally-stable resource resulting from partial consumption of elk killed by wolves. Wolves thus provided a temporal subsidy to their smaller congeners, coyotes (Canis latrans), and other vertebrate scavengers by reducing the variation in carrion availability within and across years. 


\section{Aquatic Ecosystems}

Without human interference, carrion in the ocean is infrequent in time and space (Britton and Morton 1994). Carrion availability derived from marine mammals such as whales has changed over historical time (Smith and Baco 2003). Before whaling there would have been natural mortality, leading to the majority of cetacean carcasses being made available to scavengers. Nowadays, after implementation of conservative measures, whale falls may follow a seasonal pattern according to annual migrations (Smith and Baco 2003; Roman et al. 2014) and environmental conditions occurring at that time. For instance, the unusually high mortality of grey whales (Eschrichtius robustus) along the migratory route in 1999 was linked to the undernourished body conditions displayed by the stranded animals due to low amphipod biomass, their main food source. Higher sea temperatures, together with an increase in whale population density, were hypothesised to be the principal reason explaining the fatally low prey availability (e.g. Le Boeuf et al. 2000). Little is known about temporal availability of carrion in the ocean as most of the information available on this topic is the result of analysis on seasonal patterns of strandings (Peltier et al. 2013), whereas direct observations of carcasses at sea are rare (Smith et al. 2015).

Fish populations also change in predictable ways, probably providing temporal, but also spatial, variation in the carrion they supply. Deep sea fish populations appear to respond to changes in carrion availability due to migration. Inter-annual variation in abyssal fish numbers can be linked to variation of the Pacific hake (Merluccius productus) spawning aggregation in the waters overlying them (Drazen et al. 2012). Temporal trends in fish mass mortality can be predicted by determined environmental conditions more likely to occur seasonally (Stachowitsch 1984; Schoenebeck et al. 2012) or globally driven (Marsh et al. 1999). Salmon carcasses in rivers of the northern Hemisphere are available only in a short period of time after spawning (Gende et al. 2002).

Iceberg action leading to carcass production is also highly seasonal, dropping dramatically in winter when sheets of "fast ice" lock icebergs into position and occurring again in the spring. Cold winters with longer periods of fast ice presence result in lower levels of iceberg scouring (Smale et al. 2008).

\section{Carrion Exchange at the Terrestrial-Aquatic Interface}

Coastal regions are often massively affected by marine-derived inputs transferred from the ocean to the terrestrial ecosystem (Polis and Hurd 1996a, b; Polis et al. 1997; Rose and Polis 1998) by biotic factors such as marine currents, air circulation and weather conditions. Strandings of carrion, which are the evident results of mortality events happening at sea, occur when positively buoyant carcasses disperse from the original location of death and drift towards the coastline. Natural mortality 
of cetaceans, for instance, generates single unpredictable carcasses in the ocean, which can be possibly washed on the coast. Mass stranding can be classified as unusual mortality events (UMEs; Marine Mammal Protection Act) when for initially unknown reasons a large part of the population dies. These events, whose causes can be related to biotoxins, bacteria, parasites, human interactions and oceanographic conditions, are also spatially unpredictable phenomena, in which marine mammals strand in a delimited space and during a limited time (Wilkinson 1991). Stranding data can reveal supplementary information on the spatial distribution of fatalities and their post-mortem movements: from the position of the stranding it is possible, in fact, to estimate the original location where the animal died by reconstructing the animal's drift by modelling local sea currents and tides (Peltier et al. 2012; Santos et al. 2018).

Mass mortality caused by El Niño, instead, might be predicted as it periodically affects the east-central tropical Pacific Ocean. During the El Niño, California sea lion (Zalophus californianus) fatalities were dominated by malnourished juveniles (Greig et al. 2005), as the mothers spent more time at sea searching for food, which was drastically reduced by the environmental perturbation, instead of lactating the pups (Ono et al. 1987). The lack of food and the anomalous sea conditions created during El Niño can affect the survival of seabirds, which also die at sea and are washed ashore (Piatt and van Pelt 1997).

In addition to the abiotic transfer of resources, transport of marine nutrients can also occur when animals move from one system to another. Salmon, for instance, has already been shown to play a fundamental role in this process affecting different components of the ecosystem (Cederholm et al. 1999). Every year, in defined spawning areas up stream, salmon carcasses represent a source of carrion that enriches soils and plants, locally releasing nutrients (e.g. Quinn et al. 2009; Hocking and Reimchen 2009). This impact is long term as its signal is still detectable in historically salmon-bearing stream (Koyama et al. 2005). Moreover, predictability of salmon runs in riparian systems is responsible for the synchronisation between feeding strategy and food input in black bears (Ursus americanus) and more recently in wolves (Reimchen 2000; Darimont et al. 2003). Carcasses of moose, which widely forage on aquatic plants, mean an important nutrient transfer pathway from freshwater to terrestrial systems in the circumpolar region (Bump et al. 2009).

Likewise, marine mammals affect coastal systems and their impact is substantial when they assemble in colonies for breeding. Here, they provide sources of nutrients in terms of carrion which are used either directly by above ground secondary consumers, or indirectly by increasing the input of nutrients from excreta (Anderson and Polis 1998). In Scotland, for instance, placentae and dead seals produced at a grey seal (H. grypus) colony represent a valuable food resource for scavenging gulls during the cold season (Quaggiotto et al. 2018). Due to the proximity to the sea and the inherent tidal and wave action, carcasses may be dislodged and potentially affect also the intertidal and sublittoral marine scavengers. 


\section{Conclusions and Future Perspectives}

Death is a fundamental component of ecosystems. Every year, many kilograms of carrion biomass (tens to hundreds according to the reviewed studies) are produced in terrestrial systems per $\mathrm{km}^{2}$ (see chapter "Human-Mediated Carrion: Effects on Ecological Processes" for human-mediated carrion and the possible impact of global environmental change on the spatiotemporal availability of carrion resources). This figure can be substantially higher in well-preserved coastal environments with large colonies of marine mammals. Also, salmon and other fish spawning provide massive carrion pulses. The magnitude of carcass supply, as well as its quality and availability to scavengers, is the result of many interacting factors such as animal density and turnover rates, the cause of death, carcass location, weather conditions and biotic interactions (both among and within vertebrates, invertebrates and microorganisms). In addition, carrion biomass available to scavengers may vary among species and individuals. However, despite its paramount importance for understanding carrion ecology, carrion supply remains largely understudied compared to carrion consumption. For instance, the relationship between interspecific interactions and carrion provision and nutritive value deserves further scientific attention.

The spatial predictability of carrion varies greatly, depending on carcass type, cause of death, and ecosystem. Future research on cause-specific mortality (Collins and Kays 2011) should consider reporting the exact location of death (i.e., for radiomarked animals) so that spatial variation in carrion availability can be more accurately defined. The availability of carrion to scavengers can also vary according to the temporal scale considered. In some situations, temporal variation of carrion supply is linked to spatial variation. For example, shortly after spawning (once per year), semelparous salmon die in large numbers in rivers, and many scavengers take advantage of this resource in the limited area where it occurs (Bennetts and McClelland 1991; Hewson 1995). In contrast, animals in temperate and arctic regions commonly die from starvation during extended periods of cold weather (Wilmers et al. 2003a); these carcasses are produced in a temporal pulse, but can be found scattered across extensive areas.

The spatiotemporal availability and quality of carrion can substantially influence the density and diversity of scavengers occupying an area (DeVault et al. 2003; Wilson and Wolkovich 2011; Barton et al. 2013). The growing field of scavenging ecology would benefit from further investigations quantifying the spatiotemporal availability of carrion for vertebrate scavengers across regions. More studies are needed in some continents and on islands. Quantitative studies in aquatic systems are especially encouraged, as well as those evaluating carrion exchange between terrestrial and aquatic environments. Multi-species approaches would be especially welcome. For instance, quantifying carrion biomass produced by small and highly productive animals versus large and less productive animals may be particularly interesting. The influence of microhabitat characteristics on carcass availability and accessibility to scavengers that rely on vision versus those with high olfactory skills 
should be further investigated. In summary, the fields of carrion ecology and management would largely benefit from the study of the many mysteries related to the spatial and temporal availability of carrion that remain unresolved.

\section{References}

Anderson WB, Polis GA (1998) Marine subsidies of island communities in the Gulf of California: evidence from stable carbon and nitrogen isotopes. Oikos 81:75-80

Arbelo M, de los Monteros AE, Herráez P et al (2013) Pathology and causes of death of stranded cetaceans in the Canary Islands (1999-2005). Dis Aquat Org 103:87-99

Attwell RIG (1963) Some observations on feeding habits, behaviour and inter-relationships of Northern Rhodesian vultures. Ostrich 34:235-247

Bailey DM, Priede IG (2002) Predicting fish behaviour in response to abyssal food-falls. Mar Biol 141:831-840

Barber-Meyer SM, Mech LD, White PJ (2008) Elk calf survival and mortality following wolf restoration to Yellowstone National Park. Wildl Monogr 169:1-30

Barton PS, Cunningham SA, Lindenmayer DB et al (2013) The role of carrion in maintaining biodiversity and ecological processes in terrestrial ecosystems. Oecologia 171:761-772

Beasley JC, Olson ZH, DeVault TL (2012) Carrion cycling in food webs: comparisons among terrestrial and marine ecosystems. Oikos 121:1021-1026

Begon M, Townsend CR, Harper JL (2006) Ecology: from Individuals to ecosystems, 4th edn. Blackwell Publishing, Malden

Benbow ME, Tomberlin JK, Tarone AM (2016) Carrion ecology, evolution, and their applications. CRC Press, New York

Bennett BA, Smith CR, Glaser B et al (1994) Faunal community structure of a chemoautotrophic assemblage on whale bones in the deep northeast Pacific Ocean. Mar Ecol Prog Ser 108:205-223

Bennetts RE, McClelland BR (1991) Differences in the distribution of adult and immature bald eagles at an autumn concentration in Montana. Northwest Sci 65:223-230

Birch LC (1957) The meanings of competition. Am Nat 91:5-18

Britton JC, Morton B (1994) Marine carrion and scavengers. Oceanogr Mar Biol 32:369-434

Brown LH, Watson A (1964) The golden eagle in relation to its food supply. Ibis 106:78-100

Bump JK, Tischler KB, Schrank AJ et al (2009) Large herbivores and aquatic-terrestrial links in southern boreal forests. J Anim Ecol 78:338-345

Burkepile DE, Parker JD, Woodson CB et al (2006) Chemically mediated competition between microbes and animals: microbes as consumers in food webs. Ecology 87:2821-2831

Burkholder JM, Noga EJ, Hobbs CH et al (1992) New "phantom" dinoflagellate is the causative agent of major estuarine fish kills. Nature 358:407-410

Butler JRA, du Toit JT (2002) Diet of free-ranging domestic dogs (Canis familiaris) in rural Zimbabwe: implications for wild scavengers on the periphery of wildlife reserves. Anim Conserv 5:29-37

Carter DO, Yellowlees D, Tibbett M (2007) Cadaver decomposition in terrestrial ecosystems. Naturwissenschaften 94:12-24

Cederholm C, Kunze MD, Murota T et al (1999) Pacific salmon carcasses: essential contributions of nutrients and energy for aquatic and terrestrial ecosystems. Fisheries 24:6-15

Clua EE, Manire CA, Garrigue C (2014) Biological data of pygmy killer whale (Feresa attenuata) from a mass stranding in New Caledonia (South Pacific) associated with hurricane Jim in 2006. Aquat Mamm 40:162-172

Collins C, Kays R (2011) Causes of mortality in North American populations of large and mediumsized mammals. Anim Conserv 14:474-483 
Conover MR, Dinkins JB, Haney MJ (2013) Impacts of weather and accidents on wildlife. In: Wildlife management and conservation: contemporary principles and practices. Johns Hopkins University Press, Baltimore, pp 144-155

Conybeare A, Haynes G (1984) Observations on elephant mortality and bones in water holes. Quat Res 22:189-200

Cortés-Avizanda A, Jovani R, Carrete M et al (2012) Resource unpredictability promotes species diversity and coexistence in an avian scavenger guild: a field experiment. Ecology 93:2570-2579

Cortés-Avizanda A, Jovani R, Donázar JA et al (2014) Birds sky networks: how do avian scavengers search for carrion resource. Ecology 95:1799-1808

Cowles RB, Phelan RL (1958) Olfaction in rattlesnakes. Copeia 1958:77-83

Cox P, Smith RH (1992) Rodenticide ecotoxicology: pre-lethal effects of anticoagulants on rat behavior. Proc Vertebr Pest Conf 15:165-170

Darimont CT, Reimchen TE, Paquet PC (2003) Foraging behaviour by gray wolves on salmon streams in coastal British Columbia. Can J Zool 81:349-353

DeVault TL, Krochmal AR (2002) Scavenging by snakes: an examination of the literature. Herpetologica 58:429-436

DeVault TL, Rhodes OE Jr, Shivik JA (2003) Scavenging by vertebrates: behavioral, ecological, and evolutionary perspectives on an important energy transfer pathway in terrestrial ecosystems. Oikos 102:225-234

DeVault TL, Brisbin IL Jr, Rhodes OE Jr (2004) Factors influencing the acquisition of rodent carrion by vertebrate scavengers and decomposers. Can J Zool 82:502-509

Donázar JA, Margalida A, Carrete M et al (2009) Too sanitary for vultures. Science 326:664

Drazen JC, Bailey DM, Ruhl HA et al (2012) The role of carrion supply in the abundance of deepwater fish off California. PLoS One 7:e49332

Dunlop KM, Barnes DKA, Bailey DM (2014) Variation of scavenger richness and abundance between sites of high and low iceberg scour frequency in Ryder Bay, West Antarctic Peninsula. Polar Biol 37:1741-1754

Elbroch LM, Wittmer HU (2012) Table scraps: inter-trophic food provisioning by pumas. Biol Lett 8:776-779

Evans K, Thresher R, Warneke RM et al (2005) Periodic variability in cetacean strandings: links to large-scale climate events. Biol Lett 1:147-150

Field RD, Reynolds JD (2013) Ecological links between salmon, large carnivore predation, and scavenging birds. J Avian Biol 44:9-16

Fisher I, Pain DJ, Thomas VA (2006) Review of lead poisoning from ammunition sources in terrestrial birds. Biol Conserv 131:421-432

FitzGibbon CD (1990) Why do hunting cheetahs prefer male gazelles? Anim Behav 40:837-845

Fjellheim A, Raddum GG (1990) Acid precipitation: biological monitoring of streams and lakes. Sci Total Environ 96:57-66

Geluso KN, Altenbach JS, Wilson DE (1976) Bat mortality: pesticide poisoning and migratory stress. Science 194:184-186

Gende SM, Edwards RT, Willson MF et al (2002) Pacific salmon in aquatic and terrestrial ecosystems. Bioscience 52:917-928

Gese EM, Ruff RL, Crabtree RL (1996) Foraging ecology of coyotes Canis latrans: the influence of extrinsic factors and a dominance hierarchy. Can J Zool 74:769-783

Ghalambor CK, Martin TE (2002) Comparative manipulation of predation risk in incubating birds reveals variability in the plasticity of responses. Behav Ecol 13:101-108

Glover AG, Higgs ND, Bagley PM et al (2010) A live video observatory reveals temporal processes at a shelf-depth whale-fall. Cah Biol Mar 51:375-381

Greig DJ, Gulland FMD, Kreuder C (2005) A decade of live California sea lion (Zalophus californianus) strandings along the central California coast: causes and trends, 1991-2000. Aquat Mamm 31:11-22 
Gulland FMD (2006) Review of the marine mammal unusual mortality event response program of the National Marine Fisheries Service. U.S. Dept. of Commerce, NOAA Tech. Memo, NMFS-OPR-33

Hall AJ, Connell BJM, Barker RJ (2001) Factors affecting first-year survival in grey seals and their implications for life history strategy. J Anim Ecol 70:138-149

Harvell CD, Kim K, Burkholder JM et al (1999) Emerging marine diseases-climate links and anthropogenic factors. Science 285:1505-1510

Heithaus MR, Wirsing AJ, Thomson JA et al (2008) A review of lethal and non-lethal effects of predators on adult marine turtles. J Exp Mar Biol Ecol 356:43-51

Hewson R (1995) Use of salmonid carcasses by vertebrate scavengers. J Zool 235:53-65

Hoag H (2003) Atlantic cod meet icy death. Nature 422:792

Hocking MD, Reimchen TE (2009) Salmon species, density and watershed size predict magnitude of marine enrichment in riparian food webs. Oikos 118:1307-1318

Houston DC (1974) The role of griffon vultures Gyps africanus and Gyps ruppellii as scavengers. J Zool 172:35-46

Houston DC (1979) The adaptation of scavengers. In: Sinclair ARE, Griffiths N (eds) Serengeti, dynamics of an ecosystem. University of Chicago Press, Chicago, pp 263-286

Houston DC (1985) Evolutionary ecology of afrotropical and neotropical vultures in forests. In: Buckley PA, Foster MS, Morton ES et al (eds) Neotropical ornithology. The American Ornithologists Union, Washington, DC, pp 856-864

Houston DC (1988) Competition for food between neotropical vultures in forest. Ibis 130: 402-417

Howald GR, Mineau P, Elliott JE et al (1999) Brodifacoum poisoning of avian scavengers during rat control on a seabird colony. Ecotoxicology 8:431-447

Hunter JS, Durant SM, Caro TM (2006) Patterns of scavenger arrival at cheetah kills in Serengeti National Park, Tanzania. Afr J Ecol 45:275-281

Husseman JS, Murray DL, Power G et al (2003) Assessing differential prey selection between two sympatric large carnivores. Oikos 101:591-601

Isaacs JD, Schwartzlose RA (1975) Active animals of the deep-sea floor. Sci Am 233:85-91

Janzen D (1977) Why fruits rot, seeds mold, and meat spoils. Am Nat 111:691-713

Jepson PD, Deaville R, Acevedo-Whitehouse K et al (2013) What caused the UK's largest common dolphin (Delphinus delphis) mass stranding event? PLoS One 8:e60953

Kane A, Jackson AL, Ogada DL et al (2014) Vultures acquire information on carcass location from scavenging eagles. Proc R Soc B 281:20141072

Kendall C (2013) Alternative strategies in avian scavengers: how subordinate species foil de despotic distribution. Behav Ecol Sociobiol 67:383-393

Kendall C, Virani MZ, Kirui P et al (2012) Mechanisms of coexistence in vultures: understanding de patterns of vulture abundance at carcasses in Masai Mara National Reserve, Kenya. Condor 114:523-531

Kendall CJ, Virani MZ, Hopcraft JGC et al (2014) African vultures don't follow migratory herds: scavenger habitat use is not mediated by prey abundance. PLoS One 9:e83470

Koch V, Peckham H, Mancini A et al (2013) Estimating at-sea mortality of marine turtles from stranding frequencies and drifter experiments. PLoS One 8:e56776

Koyama A, Kavanagh K, Robinson A (2005) Marine nitrogen in central Idaho riparian forests: evidence from stable isotopes. Can J Fish Aquat Sci 62:518-526

Kruuk H (1967) Competition for food between vultures in East Africa. Ardea 55:171-193

Kruuk H (1972) The spotted Hyena. A study of predation and social behavior. University of Chicago Press, Chicago

Kühn S, Bravo-Rebolledo EL, Van Franeker JA (2015) Deleterious effects of litter on marine life. In: Bergmann M, Gutow L, Klages M (eds) Marine anthropogenic litter. Springer, Berlin, pp 75-116

Laist DW, Knowlton AR, Mead JG et al (2001) Collisions between ships and whales. Mar Mamm Sci 17:35-75 
Lambertucci SA, Speziale KL, Rogers TE et al (2009) How do roads affect the habitat use of an assemblage of scavenging raptors? Biodivers Conserv 18:2063-2074

Lambertucci SA, Donazar JA, Hiraldo F (2010) Poisoning people and wildlife with lead ammunition: time to stop. Environ Sci Technol 44:7759-7760

Le Boeuf BJ, Pérez-Cortés M, Urban J et al (2000) High gray whale mortality and low recruitment in 1999: potential causes and implications. J Cetacean Res Manag 2:85-99

Margalida A, Donázar JA, Carrete M et al (2010) Sanitary versus environmental policies: fitting together two pieces of the puzzle of European vulture conservation. J Appl Ecol 47:931-935

Margalida A, Colomer MA, Sanuy D (2011) Can wild ungulate carcasses provide enough biomass to maintain avian scavenger populations? An empirical assessment using a bio-inspired computational model. PLoS One 6:e20248

Marsh R, Petrie B, Weidman CR et al (1999) The 1882 tilefish kill - a cold event in shelf waters off the North-Eastern United States? Fish Oceanogr 8:39-49

Mateo-Tomás P, Olea PP (2010) When hunting benefits raptors: a case study of game species and vultures. Eur J Wildl Res 56:519-528

Mattisson J, Andrén H, Persson J, Segerström P (2011) Influence of intraguild interactions on resource use by wolverines and Eurasian lynx. J Mammal 92:1321-1330

Mduma SAR, Sinclair ARE, Hilborn R (1999) Food regulates the Serengeti wildebeest: a 40-year record. J Anim Ecol 68:1101-1122

Moleón M, Sánchez-Zapata JA, Selva N et al (2014) Inter-specific interactions linking predation and scavenging in terrestrial vertebrate assemblages. Biol Rev 89:1042-1054

Moleón M, Sánchez-Zapata JA, Sebastián-González E et al (2015) Carcass size shapes the structure and functioning of an African scavenging assemblage. Oikos 124:1391-1403

Molinari-Jobin A, Molinari P, Loison A et al (2004) Life cycle period and activity of prey influence their susceptibility to predators. Ecography 27:323-329

Møller AP, Erritzøe H, Erritzøe J (2011) A behavioral ecology approach to traffic accidents: interspecific variation in causes of traffic casualties among birds. Zool Res 32:115-127

Morales-Reyes Z, Pérez-García JM, Moleón M et al (2017a) Evaluation of the network of protection areas for the feeding of scavengers in Spain: from biodiversity conservation to greenhouse gas emission savings. J Appl Ecol 54:1120-1129

Morales-Reyes Z, Sánchez-Zapata JA, Sebastián-González E, Botella F, Carrete M, Moleón M (2017b) Scavenging efficiency and red fox abundance in Mediterranean mountains with and without vultures. Aca Oecol 79:81-88

Moreno P, Benke H, Lutter S (1992) Behaviour of Harbour (Phocoena phocoena) carcasses in the German Bight: surfacing rate, decomposition and drift routes. Untersuchungen über Bestand, Gesundheitszustand und Wanderungen der Kleinwalpopulationen (Cetacea) in deutschen Gewässern.-Interim Report, WWF Fachbereich Wattenmeer and Nordseeschutz und Forschungs-und Technologiezentrum Westküste, Aussenstelle der Universität Kiel

Moreno-Opo R, Trujillano A, Margalida A (2016) Behavioral coexistence and feeding efficiency drive niche partitioning in European avian scavengers. Behav Ecol 27:1041-1052

Newton I (1998) Population limitation in birds. Academic, London

Newton I, Davis PE, Davis JE (1982) Ravens and buzzards in relation to sheep-farming and forestry in Wales. J Appl Ecol 19:681-706

Ogada DL, Torchin ME, Kinnaird MF et al (2012) Effects of vulture declines on facultative scavengers and potential implications for mammalian disease transmission. Conserv Biol 26:453-460

Olea PP, Mateo-Tomás P (2009) The role of traditional farming practices in ecosystem conservation: The case of trashumance and vultures. Biol Conserv 142:1844-1853

Ono KA, Boness DJ, Oftedal OT (1987) The effect of a natural environmental disturbance on maternal investment and pup behavior in the California sea lion. Behav Ecol Sociobiol 21: $109-118$

Oro D, Genovart M, Tavecchia G et al (2013) Ecological and evolutionary implications of food subsidies from humans. Ecol Lett 16:1501-1514

Owen-Smith N (1988) Megaherbivores. The influence of very large body size on ecology. Cambridge University Press, Cambridge 
Owen-Smith N, Mills MGL (2008) Predator-prey size survival rates in an African large-mammal food web. J Anim Ecol 77:173-183

Palomares F, Caro TM (1999) Interspecific killing among mammalian carnivores. Am Nat 153:492-508

Parmenter RR, MacMahon JA (2009) Carrion decomposition and nutrient cycling in a semiarid shrub- steppe ecosystem. Ecol Monogr 79:637-661

Peltier H, Dabin W, Daniel P et al (2012) The significance of stranding data as indicators of cetacean populations at sea: modelling the drift of cetacean carcasses. Ecol Indic 18:278-290

Peltier H, Baagøe HJ, Camphuysen KCJ et al (2013) The stranding anomaly as population indicator: the case of harbour porpoise Phocoena phocoena in North-Western Europe. PLoS One 8:e62180

Pereira LM, Owen-Smith N, Moleón M (2014) Facultative predation and scavenging by mammalian carnivores. Mammal Rev 44:44-55

Piatt JF, Van Pelt TI (1997) Mass-mortality of Guillemots (Uria aalge) in the Gulf of Alaska in 1993. Mar Pollut Bull 34:656-662

Polis GA, Hurd SD (1996a) Allochthonous input across habitats, subsidized consumers, and apparent trophic cascades: examples from the ocean-land interface. In: Polis GA, Winemiller KO (eds) Food webs: integration of patterns and dynamics. Chapman and Hall, Inc., New York, pp 275-285

Polis GA, Hurd SD (1996b) Linking marine and terrestrial food webs: allochthonous input from the ocean supports high secondary productivity on small islands and coastal land communities. Am Nat 147:396

Polis GA, Anderson WB, Holt RD (1997) Toward an integration of landscape and food ecology: the dynamics of spatially subsidized food webs. Annu Rev Ecol Syst 28:289-316

Pringle RM (2017) How large herbivores subsidize aquatic food webs in African savannas. Proc Natl Acad Sci U S A 114:7489-7491

Prior KA, Weatherhead PJ (1991) Competition at the carcass: opportunities for social foraging by turkey vultures in southern Ontario. Can J Zool 69:1550-1556

Putman RJ (1983) Carrion and dung: the decomposition of animal wastes. Edward Arnold, London

Quaggiotto MM, Burke LR, McCafferty DJ et al (2016) First investigation of the consumption of seal carcasses by terrestrial and marine scavengers. Glasgow Nat 26:33-52

Quaggiotto MM, Barton PS, Morris CD et al (2018) Seal carrion is a predictable resource for coastal ecosystems. Acta Oecol 88:41-51

Quinn TP, Carlson SM, Gende SM et al (2009) Transportation of Pacific salmon carcasses from streams to riparian forests by bears. Can J Zool 87:195-203

Ramirez-llodra E, Brandt A, Danovaro R et al (2010) Deep, diverse and definitely different: unique attributes of the world's largest ecosystem. Biogeosciences 7:2851-2899

Reimchen T (2000) Some ecological and evolutionary aspects of bear-salmon interactions in coastal British Columbia. Can J Zool 78:448-457

Reisdorf AG, Bux R, Wyler D et al (2012) Float, explode or sink: postmortem fate of lungbreathing marine vertebrates. Palaeobiol Palaeoenviron 92:67-81

Roman J, Estes JA, Morissette L et al (2014) Whales as marine ecosystem engineers. Front Ecol Environ 12:377-385

Rose MD, Polis GA (1998) The distribution and abundance of coyotes: the effects of allochthonous food subsidies from the sea. Ecology 79:998-1007

Ruzicka RE, Conover MR (2012) Does weather or site characteristics influence the ability of scavengers to locate food? Ethology 118:187-196

Sánchez-Piñero F, Polis G (2000) Bottom-up dynamics of allochthonous input: direct and indirect effects of seabirds on islands. Ecology 81:3117-3132

Santos BS, Kaplan DM, Friedrichs MA et al (2018) Consequences of drift and carcass decomposition for estimating sea turtle mortality hotspots. Ecol Indic 84:319-336

Savage RJG (1977) Evolution in carnivorous mammals. Palaeontology 20:237-271

Schaller GB (1972) The serengeti lion: a study of predator prey relations. University of Chicago Press, Chicago 
Schoenebeck CW, Brown ML, Chipps SR et al (2012) Nutrient and algal responses to winterkilled fish-derived nutrient subsidies in eutrophic lakes. Lake Reserv Manage 28:189-199

Scholin CA, Gulland F, Doucette GJ et al (2000) Mortality of sea lions along the central California coastlinked to a toxic diatom bloom. Nature 403:80-84

Sebastián-González E, Sánchez-Zapata JA, Donázar JA et al (2013) Interactive effects of obligate scavengers and scavenger community richness on lagomorph carcass consumption patterns. Ibis $155: 881-885$

Sebastián-González E, Moleón M, Gibert JP et al (2016) Nested species-rich networks of scavenging vertebrates support high levels of interspecific competition. Ecology 97:95-105

Selva N (2004) The role of scavenging in the predator community of Białowieża Primeval Forest (Poland). PhD thesis, Univ. de Sevilla, Sevilla

Selva N, Jedrzejewska B, Jedrzejewski W et al (2003) Scavenging of European bison carcasses in Białowieża Primeval Forest (eastern Poland). Ecoscience 10:303-311

Selva N, Jedrzejewska B, Jedrzejewski W et al (2005) Factors affecting carcass use by a guild of scavengers in European temperate woodland. Can J Zool 83:1590-1601

Shivik JA (2006) Are vultures birds, and do snakes have venom, because of macro-and microscavenger conflict? Bioscience 56:819-823

Smale DA, Barnes DKA, Fraser KPP et al (2007) Scavenging in Antarctica: intense variation between sites and seasons in shallow benthic necrophagy. J Exp Mar Biol Ecol 349: 405-417

Smale DA, Brown KM, Barnes DKA et al (2008) Ice scour disturbance in Antarctic shallow waters. Science 321:371

Smith CR, Baco AR (2003) Ecology of whale-falls at the deep sea floor. Oceanogr Mar Biol 41:311-354

Smith CR, Maybaum HL, Baco AR et al (1998) Sediment community structure around a whale skeleton in the deep Northeast Pacific: macrofaunal, microbial and bioturbation effects. DeepSea Res 45:335-364

Smith CR, Glover AG, Treude T et al (2015) Whale-fall ecosystems: recent insights into ecology, paleoecology, and evolution. Annu Rev Mar Sci 7:571-596

Soltwedel T, von Juterzenka K, Premke K et al (2003) What a lucky shot! Photographic evidence for a medium-sized natural food-fall at the deep seafloor. Oceanol Acta 26:623-628

Stachowitsch M (1984) Mass mortality in the Gulf of Trieste: the course of community destruction. PSZNI Mar Ecol 5:243-264

Stahler D, Heinrich B, Smith D (2002) Common ravens, Corvus corax, preferentially associate with grey wolves, Canis lupus, as a foraging strategy in winter. Anim Behav 64: 283-290

Subalusky AL, Dutton CL, Rosi EJ et al (2017) Annual mass drownings of the Serengeti wildebeest migration influence nutrient cycling and storage in the Mara River. Proc Natl Acad Sci U S A 114:7647-7652

Thompson D, Onoufriou J, Brownlow A et al (2015) Preliminary report on predation by adult grey seals on grey seal pups as a possible explanation for corkscrew injury patterns seen in the unexplained seal deaths. Sea Mammal Research Unit, University of St Andrews, Report to Scottish Government, no. US1 and 6 addendum, St Andrews

Tuyttens FAA, Stuyck JJJM (2002) Effectiveness and efficiency of chlorophacinone poisoning for the control of muskrat (Ondatra zibethicus) populations. N Z J Zool 29:33-40

Wikenros C, Sand H, Ahlqvist P et al (2013) Biomass flow and scavengers use of carcasses after re-colonization of an apex predator. PLoS One 8:e77373

Wilkinson DM (1991) Program review of the marine mammal stranding networks. Report to Assistant Administrator for Fisheries. NOAA

Wilmers CC, Getz WM (2004) Simulating the effects of wolf-elk population dynamics on resource flow to scavengers. Ecol Model 177:193-208

Wilmers CC, Getz WM (2005) Gray wolves as climate change buffers in Yellowstone. PLoS Biol 3:571-576 
Wilmers CC, Post E (2006) Predicting the influence of wolf-provided carrion on scavenger community dynamics under climate change scenarios. Glob Chang Biol 12:403-409

Wilmers CC, Crabtree RL, Smith DW et al (2003a) Trophic facilitation by introduced top predators: grey wolf subsidies to scavengers in Yellowstone National Park. J Anim Ecol 72:909-916

Wilmers CC, Stahler DR, Crabtree RL et al (2003b) Resource dispersion and consumer dominance: scavenging at wolf- and hunter-killed carcasses in Greater Yellowstone, USA. Ecol Lett 6:996-1003

Wilson EE, Wolkovich EM (2011) Scavenging: how carnivores and carrion structure communities. Trends Ecol Evol 26:129-135

Work TM, Balazs GH, Summers TM et al (2015) Causes of mortality in green turtles from Hawaii and the insular Pacific exclusive of fibropapillomatosis. Dis Aquat Org 115:103-110

Wright AJ, Maar M, Mohn C et al (2013) Possible Causes of a harbour porpoise mass stranding in Danish Waters in 2005. PLoS One 8(1-14):e55553 